\title{
Citizenship, Rights and Adversarial Legalism in Thailand
}

\author{
Wolfram Schaffar
}

In February 2013, several hundred demonstrators took to the streets of Bangkok and marched along the Rajadamdern Road in front of the government building to protest the EU-Thai Free Trade Agreement (Donttradeourlivesaway 2013a, 2013b). ${ }^{1}$ Bangkok has seen a lot of mass demonstrations during the past couple of years - the anti-Thaksin demonstrations in 2006, the protests of the Yellow Shirts in 2008 that culminated in the siege of the airport, the mass demonstration of the Red Shirts in 2010, which was bloodily cracked down by the military and left ninety people dead, and recently, the mobilization of the Yellow Shirts from November 2013 to March 2014 which paved the way to another coup d'état in May 2014. The demonstrations against the EU-Thai Free Trade Agreement, however, were not directly connected to the Red versus Yellow divide and were quite unique as far as their performance, and the composition and character of the protesters was concerned. The protesters were wearing white shirts, white gloves and orange headbands and appeared almost uniformed. They did not just assemble as a crowd with protest banners and megaphones, but in a very organized, nearly ritual form. They marched in a formation of several parallel rows, with their hands folded in front of their chest as if they were greeting using the traditional, respectful Wai. Following a strict choreography, all protesters kneeled down and bowed to the ground from time to time (Donttradeourlivesaway 2013a, 2013b).

The group mainly consisted of small-scale farmers and people living with HIV and AIDS (PLHA) (Pongphon 2013a, 2013b). This is a rare coalition of two interest groups who do not seem to have much in common at first sight. However, in the case of Thailand, these groups have not joined forces in a singular or spontaneous move, but represent a stable coalition that has been working together for almost a decade. In addition to the long history of their cooperation,

1 The empirical foundation of this chapter was laid in a research project on 'Constitutionalism in Thailand from the Perspective of Social Movements' supported by funds of the Oesterreichische Nationalbank (Anniversary Fund, project number 14710). The theoretical framework of citizenship I owe to Henk Schulte Nordholt, Gerry van Klinken and Ward Berenschot and our numerous discussions during my stay as research fellow at KITLV. 
the different groups show a high of degree of integration as far as their performance in public is concerned. On their banners and t-shirts, groups of PLHA do not express a specific identity as HIV-positive, at least not to the extent of PLHA groups in other parts of the world. ${ }^{2}$

The protest was also remarkable because of the slogans and demands that were voiced on the streets. In their press release, the protesters announced that they 'call for transparency and people's participation in the FTA negotiation with the EU in accordance with the Constitution's Section 19o' (Donttradeourlivesaway 2013a). What is remarkable about this demand is that it lacked any reference to specific rights. Although the immediate concern of the protesters was to secure access to drugs by protesting against a tightening of patent protection, there was no slogan referring to a specific human right to healthcare and no reference to Article 51 of the Thai Constitution that guarantees free medical treatment. Small-scale farmers, likewise, did not refer to community or other cultural rights to fence off integration in and exposition to the world market (Bencharat 2013).

According to the most common definitions, citizenship is about claiming rights through formal institutions (Marshal 1950, Isin and Turner 2002). But obviously, the demonstrators in Thailand are not behaving as an interest group who perform a specific identity and voice their concern in a language of rights. What does this example of political activism tell us about citizenship in a nonWestern, postcolonial setting like Thailand?

\section{Citizenship, Rights and Adversarial Legalism}

Citizenship is defined as the relation between a person and state authorities. Most authors distinguish between several schools of thought - republican, liberal and communitarian (Isin and Turner 2002; see also the Introduction in this volume). The liberal tradition - often departing from Hannah Arendt's famous dictum of 'the right to have rights' - sees citizenship as a legal status concerning the question in how far a person can claim universal rights. Citizenship struggles are interpreted as struggles for rights, extending citizens' rights and broadening the group of citizens who can enjoy these rights. A communitarian view also departs from a concept of rights, but draws into question the

2 When PLHA in South Africa stage a protest, for example, the performance of a specific identity as HIV-positive is a crucial element therein. To turn the diagnosis into a 'batch of pride' (Robins 2004, 2006) is part of a strategy to challenge the stigmatization as of being HIV-positive. 
universality of rights. Instead, it stresses the membership of an individual in a certain group and the relevance of this belonging for political participation. Being discussed in this perspective are differentiated forms of citizenship. In order to respond to the specific needs of ethnic, religious or other minorities, specific cultural or religious rights, rights for access to resources or services, as well as to political representation are seen as important issues. The republican tradition is less directly centred on rights but rather stresses the participation of citizens in the political processes by which rights are created and expanded.

To a different degree, and depending on the author, all these interpretations are closely connected to the concept of rights - one could also say that they are all biased towards rights-based reading. Most prominently, this bias can be found in Tilly's (1995:8) definition of citizenship. In his sociological perspective, citizenship can be observed in the everyday interactions between people and state authorities. However, as Berenschot, Schulte Nordholt and Bakker (2017) characterize it in the Introduction, 'only when these interactions involve claiming and granting of rights that are enforceable and realized in a manner devoid of personal considerations...does this transaction "count" as an instantiation of citizenship.'

The emphasis on a legal interpretation and the centrality of the notion of rights, however, mirrors a general tendency in political thinking and global political developments. For Smith (2002), this rights-centred interpretation is the result of a historic shift. Smith notices that a more rights-focused interpretation of citizenship - the liberal and communitarian interpretation - has come to the foreground at the expense of republican readings that stress political participation. He sees this shift as the result of globalization processes that have brought about the dissolution of the nation-state, which used to be the point of reference of republican citizenship engagement - according to Smith an inevitable result of globalization and yet - from a normative-ontological perspective, he criticizes it for its de-politicizing effect. ${ }^{3}$

Apart from citizenship studies, the shift towards a focus on rights and legal processes has also been noted on other levels of global political development: from a political science and sociology of law perspective, Kelemen and Sibbitt (2004) and Kelemen (2011) analyse the shift toward rights-centred public policy as an effect of the spread of the Us-American legal culture - a specific culture which has been described as 'adversarial legalism' by Kagan (2003). In contrast to other industrialized countries, where policymaking and implementation

3 As I will show later in this chapter, a turn towards rights is not the only possible development resulting out of globalization processes (cf. Demirović 2011 and Band, Görg and Wissen 2011 for a discussion of processes of internationalization or transnationalization of the state from the perspective of critical state theory). 
is achieved through the cooperation between politicians, bureaucrats and judges, the us-American system emphasizes lawyer-dominated litigation and punitive sanctions in the policy and administrative process. Kelemen argues that this system is spreading to more and more countries and regions, enabling big law firms to expand their business activities in situations of political fragmentation. I want to claim that the generalization of adversarial legalism as the unmarked global way of politics also influences the political science discourse on citizenship in so far as it suggests that the typical citizen is a rightsconscious subject who claims his/her rights through court action.

As much as a specific culture of rights and legal procedures is expanding in the industrialized world, this tendency can also be observed in and has effects on the Global South. International development institutions increasingly tend to address social and political issues as legal problems. The problem of gender discrimination, for example, the discrimination of disabled people, of ethnic, religious or other minorities is dealt with via a definition of enforceable universal human rights - in the sense of liberal citizenship - or via specific anti-discrimination laws - in the sense of communitarian citizenship. One example is the Convention on the Elimination of All Forms of Discrimination against Women (UN 1979) that has been called the Bill of Rights for Women by the United Nations. More recent examples are the Convention on the Rights of Persons with Disabilities (2006) or the Declaration of the Rights of Indigenous People (2007). The former shifted the perception of disabled people from objects of charity and medical treatment or social protection to citizens - full and equal members of society in the sense of rights-bearing subjects. Moreover, even classical socio-economic development issues such as the problem of poverty are increasingly interpreted as legal problems. Since 2008, the United Nations Development Programme (UNDP) has pursued a rights-based programme to cope with problems of inequality, entitled Legal Empowerment of the Poor and the Eradication of Poverty (UN 2009). The idea behind this programme is that poverty not only excludes people from enjoying their fundamental rights as a secondary effect, but that creating legal consciousness and encouraging people to claim their rights can serve as a strategy to overcome poverty.

The example of this legal empowerment programme illustrates the fundamental rationale behind a rights-based development approach, which relies on the intrinsic as well as instrumental value of rights. On the one hand side, the Charter of Human Rights as such is acclaimed for its intrinsic value as the only universally accepted code of values. ${ }^{4}$ On the other hand side, making use of these rights in courts is seen as a powerful tool for bringing about

4 Following Nowak, Januszewski and Hofstätter (2012) the author strongly supports the view of Human Rights as universal value system. The cases discussed in this chapter do not show 
development. A central role for the appreciation of this idea is played by the constitutional court of South Africa, which has set new global standards of the interpretation of human rights. Whereas for a long time, only so-called first and second generation rights, that is liberty rights and political rights, where seen as being enforceable, the South African constitutional court passed a number of judgements which opened a new chapter in the interpretation of social rights, such as the right to access to healthcare, housing, water, et cetera (Jones and Stokke 2005).

In order to make rights-based development work, however, it is necessary that people not only know about their rights but also internalize them and develop a consciousness as rights-bearing subjects. Only on the basis of this self-identification, the legal instruments of CEDAW or the concept of Legal Empowerment of the Poor and the Eradication of Poverty can lead to success. Legal consciousness - that is the cognitive and social processes by which individuals perceive themselves as rights-bearing subjects and give meaning to their social world according to legal concepts - is gaining more and more attention in studies of sociology or anthropology of law. Using the example of CEDAW, Merry (2001, 2006a, 2006b) has analysed the processes through which international legal norms are implemented. She characterizes the complex process through which rights are translated in different contexts as vernacularization - the emergence of a specific local legal consciousness.

All three aspects of rights-based development are addressed by more and more development cooperation programmes (see Ebenau 2012 for a critique). First and foremost, in constitutional reforms, as well as through the implementation of international rights standards, human rights are set up as legal norms and translated into national law. To unfold the instrumental power of rights, the institutional level is addressed. Capacity-building programmes for judges and bureaucrats working in the institutions of the judicial branches, are ranking high in the portfolio of international development agencies. And finally, special trainings for legal consciousness are offered to grassroots organizations.

\section{Critique}

What Merry (2001) describes as a process of vernacularization is the basis for strong criticism from Robins et al., (2008:1071). From a postcolonial perspective,

that Human Rights are not valid in the Global South. They only show that a rights discourse does not play the same central role for the notion of citizenship. 
Robins et al., criticize the idea of rights-based citizenship as a Western concept that does not make much sense in the Global South - except for an urban middle-class minority. Drawing on Chatterjee's (2004) concept of a political society, they claim that the majority of poor and powerless people have to cope with a situation of informality and illegality that forces them to muddle through by building alliances and entering clientelist relationships. Keeping rights-based citizenship as an ideal for development and democratization, they argue, amounts to a neo-colonial project of imposing Western norms on the Global South, with the goal of disqualifying the patterns of citizenship in postcolonial states as a 'cluster of absences' (Isin 2002:130). To overcome such a Eurocentric perspective, Chatterjee and Robins et al., demand that we reinterpret patronage and personalized informal networks as forms of citizenship of their own right - as genuine forms of citizenship in the South.

How do the behaviour of the Thai movements and the recent protests of PLHA fit into this picture? In what follows, I will argue that the strategy of the Thai Network of People Living With HIV and AIDS (TNP+), its coalition partners, and the identity of the members show distinctive features of a specific kind of citizenship. This pattern of citizenship is not based on a rights discourse and does not involve court action or other forms of adversarial, rightsclaiming legal activities. In so far, it differs from what mainstream citizenship literature would make us expect from a well-established democracy. However, at the same time, Thai PLHA insist on participating in the formal political process. This shows that their behaviour is also different from what can be observed as patterns of citizenship in post-Suharto Indonesia (Van Klinken 2009; Schulte Nordholt and Van Klinken 2007; Schulte Nordholt 2011). What Van Klinken and Schulte Nordholt have documented and analysed here is the emergence of citizenship patterns based on patronage, personalized and informal networks which seem to come close to what Robins, Cornwall and von Lieres (2008), drawing on Chatterjee (2004), would consider to be a type of postcolonial citizenship. Yet the demands of Thai protesters to follow the formal rules of the legislative procedures and to have an open parliamentary debate on the EU-Thai Free Trade Agreement does not fit into this category of postcolonial informal citizenship, too.

\section{Legal Consciousness and Adversarial Legality in Thailand}

Thailand has been exposed to globalization processes for a long time. Because of its entrenched pro-democracy movements, and especially in the 1990s, the 
country has been seen as a flagship of democratization in Southeast Asia. As such, Thailand was the focus of many institutions running democratization support programmes, using ideas of a rights-based development paradigm.

A landmark of this development was the promulgation of the People's Constitution in 1997, which laid the institutional foundation for rights-claiming civic action. The constitution contained a detailed and explicit Charta of fundamental rights and introduced a number institutions that should guard the compliance with these rights: a human rights commission, an anti-corruption commission, an administrative court and above all, a constitutional court. This constitutional model very much mirrored the influence of international counselling, as it was closely connected to the worldwide trend of constitutional design of the 1990s, which was based on principles of good governance and emphasized the importance of rights-bearing active citizens.

This reform process was actually initiated by a coalition of civil society organizations and the draft text was discussed in numerous public hearings prior to the promulgation. According to Munger (2006/2007), this public participation during the process of drafting a new constitution can be interpreted as sign of a mature legal consciousness in Thailand. However, based on the Asia Value Survey, he concludes that while support for democracy is ubiquitous, there is a split within the population that follows urban versus rural, modern versus traditional and more versus less educated lines. Rural, traditional, less educated people tend to accept traditional values. They reject minority rights, have more faith in social and political institutions, but show no trust in rule of law.

Engel and Engel's (2010) sociological study on the northern province of Chiang Mai illustrates this rural mind-set. Their study is based on tort cases and shows an interesting tendency: despite the progressive integration of Thailand - including Northern Thailand - into globalized economic and social exchanges, the number of tort cases where victims of traffic accidents have sued another party for compensation, have declined over the period of twenty years. As their qualitative interviews reveal, victims of traffic accidents are increasingly interpreting their accidents in terms of religious concepts. For example, as the result of bad karma of the victim, and this bad karma might have been brought about by the misbehaviour of family members. Some victims see a ghost living at the site of the accident as the reason for their misfortune. Due to Engel and Engel's interpretation, the processes of globalization, increased mobility, et cetera, have dissolved traditional forms of compensation, which relied on personal relationships, moral principles and local authorities within the community. However, new forms of rights-based, rational litigation in court have not replaced the old personalized forms. Instead of a legal analysis of the accident - an interpretation of how the accident came about as a result 
of someone else's unlawful behaviour - victims seem to resort to religious interpretations in order to give the accident a 'meaning'.

This reluctance to use courts as arenas for litigation seems to be mirrored in the political culture. As an example, Munger (2007:471) cites the Assembly of the Poor, a network of small-scale farmers and fishermen/women who staged large demonstrations throughout the 199os in opposition to destructive government-sponsored development projects. Munger notes that in their strategy, the Assembly of the Poor relied on spectacular demonstrations, media campaigns and petitions directly addressed at governmental officials. They appealed to traditional concepts of popular welfare and moral accountability instead of formal law and litigation. He draws the conclusion that in rural Thailand, where adversarial legalism is less familiar or common, Thai social movements have seldom relied on litigation to advance their goal'.

This might create the impression that rights-based interactions between citizens and the state are mainly to be found among the urban middle class in Bangkok. Chatterjee (2004) and Robins et al., (2008) consider this contrast between affluent urbanites and poor villagers typical for postcolonial states. The majority of inhabitants in rural areas outside the city perceive their fate more in terms of in religious categories. In order to get access to state resources and be heard in the political process, they have to rely on personalized, clientelist structures and they appeal to moral obligations rather than rights. The recent split between the two antagonistic political camps, the Red Shirts and the Yellow Shirts, is often interpreted along the same lines: on the one hand, the Red Shirts with their base in the poor population in the rural North and Northeast relying on Thaksin as their patron, and on the other hand, the Yellow Shirts coming from the urban middle classes in Bangkok who insist on 'clean' politics and relying on legal procedures.

However, there are a number of problems with this interpretation. Firstly, if we look into the dynamics of rural social movements in Thailand, the picture becomes less clear. For example, the Assembly of the Poor, who Munger (2007) characterizes as a rural movement relying on non-rights-based forms of activism, have not joined the camp of the Red Shirts as one would have expected. Rather, the entire movement collapsed in 2006/2007 over the question whether to support Thaksin or not. In the end, some central leaders have sided with the anti-Thaksin camp, whereas others joined the pro-Thaksin Red Shirts (Pye and Schaffar 2008).

Secondly, the Yellow and Red Shirt camps have considerably changed since they emerged in 2006. Today, it would be difficult to characterize the Yellow Shirt movement as an urban, middle-class movement representing Western ideas of rights-based citizenship. Rights and legal institutions do play a role in 
so far as the royal-conservative Yellow Shirts strategically use their privileged access to the constitutional court and other institutions to challenge the popular power of the pro-Thaksin camp. However, for their ideological foundation in their claim to power, they are more and more referring to a moral and personalized discourse that uses the monarchy as the source of legitimacy. In their rallies in 2008 and 2013, the Yellow Shirts called for a government of royally appointed, morally trustworthy people, rather than elected representatives. The Red Shirts, on the contrary, have more and more moved away from their orientation towards the strongman Thaksin. In their 2010 protests, they challenged the personalized and opaque power games of the royalist-conservative elites and called for fair and free elections and impartial courts. As Walker (2012) points out, rather than being a movement of the rural poor, one of their social bases are lower middle-class farmers who demand access to state resources including state power - on the basis of equality. This characterization of the two camps is also supported by a survey which covers the most recent demonstrations (The Asia Foundation 2013).

Thirdly, in Thailand we can observe the political dangers of a discourse which focuses on binary dichotomies like urban versus rural, Global North versus Global South, liberal versus clientelist. Robins et al., (2008) and Chatterjee's (2004) political agenda is to reject a Western discourse on citizenship that takes rational, impersonal and rights-based interpretations as norm. Their focus on divergent patterns of citizenship in the Global South intends to make visible other forms that are most often discredited as 'cluster of absences' (Isin 2002:130) in a normative discourse.

However, a focus on these different, divergent patterns - with the good intention of positive discrimination - bears the danger of 'othering' (in the sense of Spivak 1985). In the case of Thailand, this effect can be seen in the persistent debate on vote buying and clientelism in the rural areas of the North and the Northeast (Callahan 2005), which by now has developed a life of its own and is largely detached from any empirical evidence. While studies show that actual instances of vote-buying have steadily declined over the years, some academics and leaders of the Yellow Shirts insist that it is still the predominant pattern of behaviour, deeply rooted in the political culture of the North. They push this argument to the point to include Thaksin's social security and infrastructure programmes, which benefit the rural areas, as a form of 'abstract vote-buying' or legal corruption' (Thirayuth Boonmee, cited in Callahan 2005; Thongchai 2008a).

Moreover, a postcolonial discourse on different social and political patterns in rural Thailand serves as the ideological foundation for an anti-democratic alliance between leftists and royalists (Thongchai 2008b). On the basis of a 'localist' analysis, purporting that people in rural areas behave according to 
different, non-capitalist social patterns, formerly left-wing pro-democracy activists have argued that the rural masses are prone to be misguided and deceived and have to be saved from the turbo-capitalist Thaksin. Against this backdrop, left-wing activists joined hands with royal conservative elites who also oppose Thaksin and who advocate a Thai-style, royally guided democracy without popular elections.

In what follows, I will argue that the dichotomy of Western-style rights-based movements on the one hand and postcolonial personalized/clientelist style movements on the other does not adequately describe the types of citizenship one finds in Thailand. Concerning rural movements such as The Assembly of the Poor, Somchai (2006) has given a detailed analysis that goes beyond this dichotomy. He has shown that the specific organizational patterns and political demands, which Munger (2007) sees as sings of a rural mind-set, can be analysed as a conscious strategic choice. With their strategy to stage spectacular demonstrations and issue petitions directly to the prime minister, Assembly of the Poor reacted to repeated successful attempts of Thai authorities to co-opt single groups and curb rural protest in a divide-and-conquer manner. I have discussed elsewhere that the engagement of Assembly of the Poor can also be described as a kind of innovative radical democratic movement - comparable to movements of indigenous people like the Zapatista movement in Mexico or the Aymara movements in Bolivia (Schaffar 2011). In the following, I will use the example of TNP+, the Thai Network of People Living With HIV and AIDS, to show how people living with HIV and AIDS (PLHA) developed a form of citizenship that is neither rights-based, or 'Western', in the terms of Robins et al., (2008) and Chatterjee (2004), nor clientelist.

\section{HIV Activism in Thailand}

In Thailand, the first cases of HIV and AIDS were diagnosed as early as 1984the very beginning of the global AIDS crisis. Unlike most industrialised countries, where prevention programmes had quickly been implemented, the lack of funds and regulatory capacity was the reason why in Thailand, at the onset of the 1990s, the epidemic seemed to have gotten out of control with 140,000 new infections per year. It was only due to a concerted effort of key ministries, NGOs, the media, communities, the private sector and the police that Thailand could evade an existential health crisis. However, although Thailand managed to reduce the infection rate dramatically within only a few years, the high infection rates of the 1990s had left more than 600,00o people infected with HIV, with the immediate need to get access to medical care. 
Around the mid-1990s, several anti-retroviral substances were found to suppress the reproduction of the virus inside the human body. Although the infection could not be cured, a continuous treatment with a combination of two to three anti-retroviral drugs can stabilize the condition of a patient for many years. This treatment soon became the standard treatment in most countries in the North and changed the perception of HIV and AIDS from a fatal diagnosis to a chronic disease like diabetes. In the countries of the Global South, however, anti-retroviral medication was not available. Since anti-retroviral treatment requires a developed medical infrastructure, regular blood checks and strict adherence, it was long seen as not feasible in the Global South. Apart from technical and infrastructure problems, the most serious obstacle for access to drugs was their price. Since many of the anti-retroviral drugs were available only as brand-name drugs, the cost of imported drugs was too high for most developing countries. In 1995, a pilot project of the World Bank, the World Health Organisation and the Ministry of Public Health in Thailand came to the conclusion that treatment of HIV could not be implemented in Thailand since the 'cost [was] higher than the benefits' (Ford 2004).

The origins of TNP+, the Thai Network of People Living With HIV and AIDs, lie in Northern Thailand. The reason why this rural area is one of the hotspots of the Thai epidemic is due to the circular migration pattern of Thai internal labour migrants. Young men and women from the provinces regularly migrate to find seasonal jobs in the urban centres of Bangkok, Chiang Mai or Pattaya. Many of those working in the lucrative sex business of the touristic areas got infected and brought back the virus to the countryside upon returning home.

The denial of access to medication for PLHA, some of whom had already been taking part in pilot projects for anti-retroviral treatment and were sent away after the project ran out, triggered a process of self-organization. According to Wirat Purahong, president of TNP+, the founding of TNP+ was an act of self-empowerment (Lyttleton, Beesey and Sitthikriengkrai 2007). Central to this empowerment was the establishment of so called Buyers' Clubs - semi-formal structures where PLHA organized the procurement and allocation of life-saving drugs in cooperation with NGOs like Doctors without Borders. The first club was established in a hospital in Rayong at the initiative of a nurse working for Doctors without Borders. The group of PLHA was given a room inside the hospital where they could store and administer a stock of essential drugs, some of which had to be imported illegally from India since they were only available as brand-name drugs that were prohibitively expensive in Thailand (Sripen and Gill 2008:333-334). At its height, twenty-one branches of the Buyers' Club operated throughout Thailand and secured the supply of 
drugs for more than 1,000 patients (Niprapa et al., 2005:10), many of whom would have died without this support.

The co-operation between TNP+ and international NGOs like Doctors without Borders made Thai PLHA (People Living with HIV and AIDS) experts in the field of medical treatment, medical infrastructure and health politics. This engagement with state structures on a local level was crucial for the integration of anti-retroviral treatment into the framework of the newly established Thai universal healthcare system.

For decades, Thai unions and social movements had been demanding improvements in healthcare provision. However, in order to provide for an investment-friendly climate, earlier governments had persistently left this field unregulated (Amara, Rakawin and Nauemol 2002). The result was that until the late 199os, the Thai health insurance system consisted of several different schemes and was highly fragmented: in 1974, a tax-funded healthcare scheme for civil servants had been introduced. During the 1980s, several local insurance schemes and special programmes for the poor had been introduced. A first major reform step was taken with the Social Security Act of 1992 that introduced a corporatist tripartite insurance system tied to formal working contracts. Despite the great number of different programmes, by the mid-199os, more than thirty percent of the population was left without health insurance and this number dramatically increased during the Asian Crisis, as more and more people lost their formal employment and had to resort to (unprotected) informal work (Schramm 2002).

Against this backdrop, Thaksin Shinawatra introduced a tax-financed universal healthcare programme overnight. In 2001, Thaksin had won the general elections with a great majority. One of his central promises was to lift Thailand out of the economic stagnation that followed the Asian financial crisis of 1997. He pursued a dual programme of neo-liberal privatization and, at the same time, investment programmes for infrastructure and the introduction of a new healthcare scheme.

Under the so-called 30-Baht programme, every Thai citizen could register at a hospital and - with a fee of 30 Baht per visit - get medical treatment (Hughes and Songkramchai 2007). The neo-liberal opposition harshly criticized the programme as populist and not sustainable since its financial basis was not solid. Some patient groups criticized it for its poor quality. However, in terms of citizenship, it was revolutionary. Instead of a number of different targeted programmes, which addressed individual groups and led to a highly fragmented system of healthcare, the new programme formulated and implemented a universal right to healthcare that was tied to Thai citizenship. 
Somewhat in contradiction to its principle of universality, though, treatment of HIV was not included in the programme when it was first implemented. The reason was that there were doubts about the programme's budgeting, especially because the costs for anti-retroviral medication were expected to be incalculable due to the high prices of the drugs, the large number of infected people and the need for life-long medication of each patient. Here, the commitment of local PLHA groups came into play. With their experiences of self-organizing in Buyers' Clubs, the HIV groups were able to argue on the basis of the prospective price development of Indian generics that, in principle, a treatment scheme was possible. In October 2001, the Government Pharmaceutical Organization - the state-owned pharmaceutical company - launched a fixed-dose combination of anti-retroviral drugs on the basis of patent-free substances (Sripen and Gill 2008; Ford et al., 2009). Under the pressure of political campaigns, the Ministry of Public Health finally agreed to include anti-retroviral medication in the universal access to healthcare policy. This process was completed in 2003 with the establishment of the National Access to Antiretroviral Programmes for People living with HIV/AIDS. PLHA were integrated into all relevant medical and political planning processes, such as those concerning the definition of the standards of treatment or budget allocation. Sripen and Gill, (2008) consider this step a change in quality as far as the cooperation between progressive ministerial bureaucracy and PLHA groups is concerned.

In terms of citizenship this development is remarkable. In many developing countries, HIV programmes have developed into parallel structures to public healthcare systems. In some poor areas, this has led to the paradox situation that healthcare for HIV positive people - because it is funded by foreign donors and run by international NGOS - is better than the public healthcare system and there are reports of people getting infected deliberately in order to access special support programmes. In Thailand, the establishment of Buyers' Clubs could also be seen as a parallel structure to provide access to drugs that were not available on a regular basis through the public institutions. However, these structures were integrated into and cooperated with public hospitals. Moreover, this parallel structure was always seen as provisional and was dissolved as soon as a new universal public scheme was established.

\section{Political Action and Citizenship: PLHA and Adversarial Legalism}

As smooth and cooperative as this process of establishing a public universal institution of HIV treatment might appear, the integration of HIV treatment 
into the universal health scheme on the basis of domestically produced generic drugs was the result of a highly contested process of political struggle and engagement of individuals and civil society groups (Ford, Wilson, Chaves, Lotowska and Kannikar 2007; Ford et al., 2009). The critical question was how to secure the production or import of generic anti-retroviral drugs. Under pressure from the us government, Thailand had reformed its patent laws as early as 1992. Under the new provisions, pharmaceutical substances were able to receive patent protection for twenty years, long before newly industrialized countries were obliged to implement these standards under the TRIPS treaty ${ }^{5}$ of the World Trade Organisation (Jiraporn 2005). When the Thai Ministry of Public Health was preparing the introduction of a triple therapy on the basis of generically produced didanosine in 1999, the patent holder, Bristol-Myers Squibb, intervened and prohibited the production (Weeraboon 2004). In turn, Bristol-Myers Squibb offered to sell didanosine to Thailand at a special price, which was still much higher than the generic drug would have cost.

Against this backdrop PLHA groups and NGOs called for compulsory licensing as a way to legalize generic production without the consent of the patent holder. Compulsory licensing is a tool that is explicitly allowed by the World Trade Organisation, especially in cases where health hazards have to be dealt with. However, due to the pressure from industrialized countries and pharmaceutical companies, no country in the developing world dared to make use of this flexibility (Ford, Onanong and Von Schoen Angerer 2004:56o). When the Government Pharmaceutical Organisation formally asked for compulsory licensing in order to be entitled to produce didanosine tablets in 1999, the Thai Ministry of Public Health denied the request.

When it became clear that the possibility of resorting to compulsory licensing was barred, PLHA groups decided to challenge the patent judicially for the first time. Flaws in the application process of the patent promised a chance to win against Bristol-Myers Squibb in court. Under the leadership of the Drug Study Group, an NGO comprised of committed pharmaceutical researchers, the AIDS Access Foundation and the Health and Development Foundation, a working group was formed that coordinated the cooperation of a broad network and prepared for the law suit. The Law Society of Thailand, a professional organization of lawyers in Thailand, provided a lawyer pro bono, and Doctors without Borders supported the coordination group with one full-time project manager (Weeraboon 2004; Ford et al., 2009). In May 2001, two PLHA, together

5 Trade Related Aspects of Intellectual Property Rights (TRIPS) is the treaty of the World Trade Organisation which defines the standards of patent protection for the wTo member countries. 
with the AIDS Access Foundation, filed a lawsuit against Bristol-Myers Squibb at the Central Intellectual Property and International Trade Court of Thailand. Instead of a judicial evaluation of procedural errors concerning the issuing of the patent, the litigation had to firstly evaluate whether patients could be accepted as litigants in patent disputes at all - a status commonly restricted to companies and countries (Weeraboon 2004:57; Ford et al., 2004:561).

Meanwhile, the Thai struggle against patents had become an issue at the World Trade Organisation Ministerial Conference in Seattle in December 1999, and the outrage over the effects of the restrictive interpretation of TRIPS (the patent treaty) was one factor that led to the historic collapse of the trade negotiations. In the same month, about hundred PLHA organized a protest camp in front of the Ministry of Public Health and became publically visible for the first time. At the 2001 ministerial conference in Doha, Qatar, which was overshadowed by the 9/11 terrorist attacks, the World Trade Organisation felt obliged to openly react to the critique of developing countries, NGOS and social movements and issued the so-called Doha Declaration, which re-affirmed the possibility of compulsory licensing as one aspect of legal flexibility of the patent agreement and also the fundamental right of patients to have access to treatment (WTO 2001).

In its first ruling in October 2002, the Thai court decided in favour of the litigants and explicitly accepted patients as plaintiffs. In addition, the court mentioned in its ruling that medical drugs are to be differentiated from other consumer goods in so far as the lack of access to drugs due to high prices violates the human right of access to healthcare (Ford et al., 2004:561).

The three plaintiffs have the right to pursue the case.... Medicine is one of the fundamental factors necessary for human beings, as distinct from other products of other inventions that consumers may or may not use for consumption.... Lack of access to medicines due to high price prejudices the human rights of patients to proper medical treatment.

WEERABOON 2004:57

To the same extent that this ruling was a novelty in the Thai jurisdiction, it set a precedent in worldwide trade and intellectual property rights litigation. Most importantly, however, it meant a step in the direction of a specific kind of citizenship interpretation. With this ruling, Thai PLHA were officially accepted and established as rights-bearing subjects who are able to utilize the human right to access to medication as a legal tool. Very much like the precedent set by the constitutional court of South Africa in its ruling on social rights such as access to water and housing (Jones and Stokke, 2005), the Thai ruling had not 
only an impact on the domestic legal system but also on a global level (Weeraboon 2004). Moreover, it meant a shift in the legal consciousness of the PLHA and activists involved in the process.

Before this time, NGOs were only involved with campaigning and training, but with this issue, I had to familiarize myself with anti-retroviral medicines, patents, TRIPS and WTO

SANGSIRI tREEMANAKa, coordinator of Access Foundation, cited in Weeraboon 2004:46

We need to catch up on the legal details. We must know what academics mean.

NIMIT TIEN-UDOM, Aids access manager

What we can see are signs of the emergence of a rights-based concept of citizenship. Just as in the Us, in Thailand, too, adversarial litigation appeared as a promising tool to achieve a change in public policy. However, in so far as key figures of the campaign were highly educated NGO workers and academics, one can argue that this rights-based pattern of citizenship was linked to a specific social class. ${ }^{6}$ In the same vein, we see the influence of international actors NGOs such as Doctors without Borders and other actors of the globalization critical movement who were acquainted with Us-American-style patterns of political campaigns and introduced them in Thailand.

However, unlike the movements in South Africa where the entire PLHA movement centred very much on legal action in several court cases (Bilchitz 2003; Jones 2005), for Thai PLHA, the court case was merely an episode. In fact, the working group under the leadership of the Drug Study Group used the first verdict and its reference to the Doha Declaration to prepare for a second

6 I am grateful to Henk Schulte Nordholt for pointing out this connection to class. There is clearly a class issue in Thailand which deserves further study. Especially because 'rights talk' seems to be identified as an element of middle and upper-class life style in more and more countries around the world. The rejection of 'rights talk' - including the rejection of minority rights and other liberal rights - serves as a populist foundation for right-wing mobilization. As I have argued earlier in this chapter, the dichotomy between middle and upper-class rights consciousness and lower class right-wing rejection of rights talk is not borne out in Thailand's split between Yellow and Red Shirts. The Red Shirts are no right-wing movement, and the Yellow Shirts are no liberals. However, in Hungary, India, Ukraine and many other countries, where liberal rights are identified as part of a neo-liberal economic project of domestic middle and upper classes, anti-neo-liberal movements often take the shape of rightwing movements who reject political liberalism. 
lawsuit, which no longer aimed at procedural errors but at the legitimacy of the patent itself. However, in order to prevent another ruling that might constitute a precedent, in late 2003, Bristol-Myers Squibb offered an out-of-court settlement to the plaintiffs. TNP+ and the Drug Study Group, tired of years of judicial dispute during which several members of the PLHA groups had already died - some due to the lack of access to medical drugs - accepted the settlement (Weeraboon 2004:64-6).

\section{Political Action and Citizenship: Mobilization on the Streets}

Despite this partial success, access to anti-retroviral medication was only secured for a short period of time and it was clear that the problem of patent protection and intellectual property rights would soon re-occur in an even more serious form.

The anti-retroviral medication provided for by the Government Pharmaceutical Organisation was mainly based on a combination of so-called first-line drugs, that is drugs that were developed at an early stage of the HIV epidemic and for which the patent protection had already expired. In the course of the medical treatment, however, the virus inevitably develops resistance, meaning that at later stages of treatment, certain first-line substances have to be substituted for so called second-line drugs. Since these drugs result from relatively recent medical research, most of them are protected for at least another five years under legally indisputable patents. Another obstacle was that the transitional arrangements for the implementation of the TRIPS provisions for middle-income countries expired in 2005. This meant that countries like India had to fully comply with higher patent protection standards by that date. The direct consequences were that the import and export of generic drugs was hindered and competition between different generic producers, a main trigger for cheap prices, was undermined.

As with other countries with a considerable population of PLHA, the new development posed serious problems for Thailand: without access to cheap, generic versions of second-line anti-retroviral drugs, the whole project of providing access to anti-retroviral medication under the universal coverage scheme would become unaffordable. To make things worse, in 2005, the administration of the newly re-elected government of Thaksin Shinawatra spurred up their engagement to negotiate a Free Trade Agreement with the US. As with most bilateral trade agreements, the Thai-US Free Trade Agreement contained so-called 'TRIPS plus' provisions which went beyond the patent agreement of 
the World Trade Organisation, guaranteed longer periods of patent protection and excluded flexibilities such as compulsory licensing.

This is the scenario that forced PLHA to take political action again. The coalition they joined, however, was quite different from the network that was behind the courts cases. On the basis of the common threat of the free trade agenda being pushed by the World Trade Organisation on an international level and by the us-Thai Free Trade Agreement on a bilateral level, TNP+ became a founding member of a network named FTA Watch. Here they joined forces with farmers' organizations who feared the ruinous competition of us-American farmers as well as with consumer groups who feared further deregulation and lowering of product standards (Chanida and Bamford 2005). From a Western perspective, a coalition between small-scale farmers and PLHA seems highly improbable. However, in Thailand, it was not only a short-term strategic cooperation, but a long-term coalition. One reason might be that, differently from the West where HIV is a predominantly urban phenomenon, the hot spots of HIV in Thailand have long been in rural areas due to cyclic migration of sex workers.

In December 2005, FTA Watch mobilized to protest against the negotiation round of the World Trade Organisation in Hong Kong. There, TNP+ and Thai farmers joined forces with farmers from Korea who had the reputation of being very disciplined, radical and militant. Their protest included ritual marches in military-like formations, a strict choreography of kneeling down on the pavement and bowing to the ground and eventually, militant action against the barricades of the police. One action that got a lot of media attention was the attempt to use swimming vests and swim over to the offshore convention centre where the WTO ministerial conference was being held. Together with the Korean farmers, Thai PLHA were detained by the Chinese police and suffered severe human rights violations in prison (Hong Kong People's Alliance on wTO 2006). A few weeks later, in January 2006, FTA Watch took to the streets of Chiang Mai where the final negotiations on the Us-Thai FTA were being held. About 10,000 farmers and PLHA staged a protest using Korean-style choreography and eventually caused the breakdown of the meeting. This political success was a milestone in the history of the network and it is one of the foundations of the close cooperation between Thai PLHA and small-scale farmers. The strategy which FTA Watch used in Bangkok in February 2013 to protest against the EU-Thai FTA - mentioned in the introduction to this chapter - is a reminiscence to the events in 2005/2006.

The year 2006 also saw the emergence of a first wave of anti-Thaksin protests in Bangkok. When they first mobilized, the People's Alliance for 
Democracy - a predecessor of what later became the royalist-conservative Yellow Shirts - managed to draw together various movements and NG OS. In order to stop Thaksin's free trade policy, FTA Watch also agreed to join the protests. ${ }^{7}$ With this move, the protests gained momentum and legitimacy and drove the Thaksin government into the defensive (Pye and Schaffar 2008). In the resulting political stalemate, and due to increasingly radicalized and undemocratic parts of the People's Alliance for Democracy, the military eventually moved in, staged a coup d'état and removed Thaksin from office (Hewison 2008).

Generally speaking, the coup of 2006 meant a severe setback for the democratization process in Thailand: a months-long curfew, the introduction of new and strict internet censorship, and a gross violation of human and political rights. Moreover, the violent interruption of the political process deepened the emerging divide in Thai society, brought Thailand close to civil war and caused the death of many people in the subsequent protests. In the short-term, however, the installation of a military-sponsored government was a window of opportunity for two major achievements for TNP+ and FTA Watch.

Firstly, the new minister of health, Monkhol na Sonkhla, issued compulsory licences on five essential drugs for treating HIV, cancer and heart diseases in December 2006 and January 2007. This step was met with fierce criticism from the side of international pharmaceutical companies, but was soon copied by other countries with similar problems such as Brazil and thus set new global standards in the interpretation of TRIPS flexibilities (Schaffar 2014).

Secondly, and equally important, FTA Watch managed to take an active position during the drafting process of a new constitution in 2007. The militarysponsored drafting committee had a contradictory task to fulfil. On the one hand, the royalist-conservative elites wanted to make sure that Thaksin could not come back to power despite his unbroken popularity. On the other hand, the military had to show their intention to introduce a better democratic system than Thaksin's allegedly corrupt system. FTA Watch could use the quest for democratic legitimacy of the drafting committee and lobbied successfully for provisions. However, contrary to what one might expect from a rights-based perspective, the member groups of FTA Watch did not lobby for the codification of specific rights - such as the right to access to drugs or medical care, the

7 As mentioned earlier in this chapter, the PLHA groups and small scale farmers were not directly linked to the Yellow - Red divide. However, since FTA Watch used the mobilization of the anti-Thaksin movement in 2006 to push for their cause, they are considered as Yellowish, especially by activists from the Red camp. As for the content of their claims, the rejection of a rights-based approach and the insistence on parliamentary processes would rather be an issue raised by the Red Shirts. 
right to land or indigenous rights that have been used in other countries to fight for access to land and protection of small scale farming (Rachman 2013; Bencharat 2013). Instead, FTA Watch concentrated on one single provision: an article that guaranteed that international treaties have to be discussed in parliament and must be publicly disclosed during the negotiation process. This provision was taken into the constitution of 2007 as Section 190 and it was another milestone of the political success of FTA Watch. The central demand of the protesters in Bangkok in 2013 to publicly disclose the negotiation papers of the EU-Thai Free Trade Agreement - mentioned in the introduction to this chapter - refers to this provision. In a global perspective, Section 190 is a unique article which was much acclaimed by international NGOS and discussed as an example for the strategies to be employed in Europe as well. ${ }^{8}$

\section{Towards Republican Citizenship in the Global South}

In 2004, TNP+ abandoned the legal arena. The experience of their court case against Bristol-Myers Squibb had shown that contrary to the expectation of a rights-based development paradigm, claiming rights in court did not result in a sustainable solution to the problem of securing access to anti-retroviral drugs. The right to access to healthcare was under permanent threat, especially due to the free trade agenda on the national and international level. In the course of the years 2003/2004, it became clear that the power relations and interests of transnational pharmaceutical companies that were behind this agenda had to be challenged by different means. The crafting of a broad and powerful coalition between the various groups affected by the free trade policy, however, made it necessary to move beyond particularistic claims for single issues and to generalise political demands. During the years 2004 through 2006, FTA Watch facilitated a close communication between the very different groups and whenever any group was about to publish a statement on trade issues, the content was communicated and discussed with all other members of the network.

This generalization of political claims and the integration into a broader movement that went beyond health groups corresponds to the concept of identity of TNP+. For a long time, the (international) perception of HIV in Thailand was dominated by Buddhist charity institutions like the so called AIDs temple,

8 At the occasion of the Asia Europe Peoples' Forum in Brussels in 2010, social movements and NGOs working on free trade agreements in different countries repeatedly referred to Section 190 of the Thai Constitution. 
Wat Prahbat Namphu, a hospice in Lopburi where AIDS patients seek refuge in the final stages of their disease to receive medical treatment or simply to die. The handling of the disease is embedded in a religious context and draws on the widespread believe that an HIV infection is a consequence of bad karma (Ross, Wilaiphan Draucker and Tatirat 2007). Enduring the suffering and using the final days of their lives to pray and earn merit serves as a strategy for coping with the disease and achieving better karma for the next life.

TNP+, however, rejects this charity-based, Buddhist approach with its focus on suffering, death and rebirth. Instead, TNP+ promotes a bio-medical approach, stressing that AIDS is caused by a viral infection and that HIV positive people - under the condition that they have access to treatment - are not closer to death than anyone else. The name of the group TNP+ 'People LIVING with HIV and AIDs' is a programmatic statement.

Rejecting a religious concept of bad karma, however, does not mean that TNP+ took the same road as Treatment Action Campaign in South Africa who pursued the strategy to turn their infection status into a 'batch of pride' to fight discrimination (Robins 2004 2006). The 'positive identity' that is promoted by $\mathrm{TNP}+$ is rather centred on the concept of normalcy. This is best mirrored in the material produced by TNP+ for public education. In the short films and video clips such as My Positive Life, TNP + features the everyday life of common people - a lady working in an office, a farmer, a young man courting his girlfriend, et cetera. The short film My Dream features a young man who dreams of becoming a soldier but is confronted with a positive result of an HIV test. In all these films, there is almost no mention of how people got infected but the focus is rather on how to cope with the infection in daily life. The main message is clear: if people have access to anti-retroviral drugs, and if discrimination is overcome, PLHA can lead a normal life as farmers, soldiers, secretaries, and thus serve society.

This stress on normalcy and on participating in society is in stark contrast to what Nguyen (2010) and Robins (2004) report on the transformation of HIV positive people in Western Africa or South Africa. What Nguyen calls 'therapeutic citizenship' is the result of a near-death experience that many HIV-positive people in West Africa share. Those patients who - after having developed serious AIDS symptoms - manage to get chosen to participate in an anti-retroviral treatment programme, report how this experience of being rescued turned them into politically aware citizens whose new life is centred around the question of fighting for access to the drugs, including political activities to secure anti-retroviral treatment programmes. In the case of South Africa, this new form of citizenship is closely connected to the identity of turning their HIV status into a 'batch of pride' and rights-claiming action in court. 
In Thailand, on the other hand, TNP+ stresses that PLHA are just ordinary people - albeit ready to take militant action if they find themselves confronted with interests of pharmaceutical companies or unco-operative bureaucrats in the Ministry of Public Health.

PLHA in Thailand, in their struggle for access to anti-retroviral drugs and in their everyday routines of interaction with state authorities, show a specific type of citizenship. This pattern is neither based on adversarial rights-claiming in court, nor a 'muddling through' on the basis of clientelist or informal political action. Rather than a particularistic claim to rights, they base their engagement on generalised political claims. This became clear in their positioning towards the EU-Thai FTA in 2013 which was mentioned in the introduction to this chapter. FTA Watch did not oppose free trade as such on the ground that it has a negative impact on PLHA and farmers. Rather, they drew on Article 190 of the constitution and demanded that an FTA - as much as all international contracts with impact on public policy - has to be disclosed to the public. This reveals a high confidence that a public debate will yield the right decision - a kind of confidence in the public sphere that is reminiscent of Habermas' republican concept of deliberative democracy and the belief in 'the non-coercive coercion of the better argument' (Habermas 1990:132).

Any concept of citizenship in postcolonial countries that operates with the dichotomy of a rights-conscious, urban middle class versus a clientelist, rural, poor population runs into difficulties with regard to the dynamics of citizenship in Thailand. Firstly, it seems that focusing on this dichotomy obscures the fact that a rights-based interpretation of citizenship is not so much the unmarked case of 'Western' citizenship but rather a generalization of us-American exceptionalism, which is contested in the Global South as much as in the Global North. Secondly it obscures the dynamic, innovative and democratic patterns of citizenship in postcolonial countries, such as FTA Watch's successful lobbying for Section 190 in the Thai Constitution, which guarantees political participation in the republican sense of citizenship.

\section{References}

Amara Pongsapich, Rakawin Leechananichphan and Nauemol Bunjongjit (2002). Social Protection in Thailand. In E., Adam, M. von Hauff, and M. John (eds.), Social Protection in Southeast and East Asia. (pp. 313-362). Singapore: Friedrich Ebert Foundation.

Bencharat Sae Chua (2013). Rights Claims and Strategic Use of Culture to Protect Human Rights: The Community Forest Movement in Thailand. In B. Coeli (ed.), 
Rights to Culture. Heritge, Language, and Community in Thailand. (pp. 85-114). Chiangmai: Silkworm.

Berenschot, W., Schulte Nordholt, H. \& Bakker, L. (2017). Citizenship and Democratization in Postcolonial Southeast Asia. In: W. Berenschot, H. Schulte Nordholt, \& L. Bakker (Eds.) Citizenship and Democratization in Southeast Asia (pp. 1-32). Leiden: Brill Publishers.

Bilchitz, D. (2003). South Africa: Right to health and access to HIV/AIDS drug treatment. International Journal of Constitutional Law, 1(3), 524-534. doi: 10.1093/icon/1.3.524.

Brand, U., Görg, C. \& Wissen, M. (2011). Second-Order Condensation of Societal Power Relations: Environmental Politics and the Internationalisation of the State from a Neo-Poulantzian Perspective. Antipode 43(1), 149-175. doi: 10.1111/j.1467-8330.2010.00815.x.

Callahan, W.A. (2005). The Discourse of Vote Buying and Political Reform in Thailand. Pacific Affairs, 78(1), [Democratization and Communication in Asia] pp. 95-113. doi: $10.2307 / 40023443$.

Chanida Chanyapate Bamford \& Bamford, A. (eds.). (2005). Free Trade Agreements and Their Impacts on Developing Countries: The Thai Experience. Bangkok, FTA Watch.

Chatterjee, P. (2004). The Politics of the Governed: Reflections on Popular Politics in Most of the World. New York: Columbia University Press.

Demirović, A. (2011). Materialist State Theory and the Transnationalization of the Capitalist State, in: Antipode 43(1), 38-59. doi: 10.1111/j.1467-8330.2010.00810.x.

Donttradeourlivesaway (2013a). CSO's Thailand-EU FTA campaign kick-off. http:// donttradeourlivesaway.wordpress.com/2013/02/28/csos-thailand-eu-fta-campaign -kick-off/.

Donttradeourlivesaway (2013b). Civil Society's protest against the Thai-Eu FTA. http:// donttradeourlivesaway.wordpress.com/2013/03/o1/civil-societys-protest-against -the-thai-eu-fta/.

Ebenau, M. (2012). 'Recht und Entwicklung' bei der Weltbank: Eine Kritik. Peripherie, 125(32), 43-66. http://www.zeitschrift-peripherie.de.

Engel, D.M. \& Engel, J.S. (2010). Tort, Customs, and Karma. Globalization and Legal Consciousness in Thailand. Stanford: Stanford University Press.

Ford, N. (2004,). Patents, Access to Medicines and the Role of Non-Governmental Organisations. Journal of Generic Medicines, 1(2), 137-145. doi: 10.1057/palgrave. jgm.4940005.

Ford, N., Wilson D., Onanong Bunjumnong, \& von Schoen Angerer, T. (2004). The role of civil society in protecting public health over commercial interests: lessons from Thailand. The Lancet 363:56o-563. doi: 10.1016/So140-6736(04)15545-1.

Ford, N., Wilson, D., Chaves, G.C., Lotowska, M. \& Kannikar Kijtiwatchakul (2007). Sustaining access to antiretroviral therapy in the less-developed world: Lessons from Brazil and Thailand. AIDS 21(suppl 4), 21-29. doi: 10.1097/01.aids.0000279703.78685. a6. 
Ford, N., Wilson, D., Cawthorne, P., Aree Kumphitak, Siriras Kasi-Sedapan, Suntharaporn Kaetkaew, Saengsri Teemanka, Boripat Donmon, \& Chalerm Preuanbuapan (2009). Challenge and Co-operation: Civil Society Activism for Access to HIVTreatment in Thailand. Tropical Medicine and International Health 14(3), 258-266. doi: 10.1111/j.1365-3156.2009.02218.x.

Habermas, J. (1990). Moral Consciousness and Communicative Action. Cambridge, MA: M.I.T. Press.

Hewison, K., (2008). A book, the king and the 2006 coup, Journal of Contemporary Asia, 38(1), 190-211. doi: 10.1080/00472330701652026.

Hong Kong People's Alliance on WTO (2006). Human Rights Violations during the Policing, Arrests, and Detentions during the WTO Protests in Hong Kong, December 2005 (Submission to the 86th Session of the U.N. Human Rights Committee: Consideration of the Second Report of the Hong Kong Special Administrative Region of the People's Republic of China in light of the International Covenant on Civil and Political Rights, Prepared by: Hong Kong People's Alliance on WTO Asian Human Rights Commission, 15 3. 2006), http://www.ahrchk.net/pdf/HKPA_AHRC-UNReport2oo6. pdf (25. 4. 2006).

Hughes, D. \& Songkramchai Leethongdee (2007). Universal Coverage in the Land of Smiles: Lessons from Thailand's 30 Baht Health Reform. Health Affairs, 26(4), 999-1008. doi: 10.1377/hlthaff.26.4.999.

Isin, E.F. \& Turner, B.S. (2002). Citizenship Studies: An Introduction. In Engin F. Isin \& Bryan S. Turner (eds.) Handbook of Citizenship Studies. (pp. 1-10). London: Sage.

Jiraporn Limpananont (2005). Impact of US-Thailand FTA in Access to Medicines in Thailand. In Chanida Chanyapate Bamford and A. Bamford (eds.), Free Trade Agreements and Their Impacts on Developing Countries: The Thai Experience. (pp. 59-74) Bangkok, FTA Watch.

Jones, P.S. (2005). 'A Test of Governance': Rights-Based Struggles and the Politics of HIV/AIDS in South Africa. Political Geography 24(4), 419-447. doi: 10.1016/j. polgeo.2004.10.012.

Jones, P. \& Stokke, K. (eds.) (2005). Democratising Development. The Politics of SocioEconomic Rights in South Africa. Boston: Martinus Nijhoff Publishers.

Kagan, R.A. (2003). Adversarial Legalism. The American Way of Law. Cambridge: Harvard University Press.

Kelemen, R.D. (2011). Eurolegalism: The Transformation of Law and Regulation in the European Union. Harvard University Press.

Kelemen, R.D. \& Sibbitt E.C. (2004). The Globalization of American Law. International Organization, 58(1), 103-136. doi: http://dx.doi.org/10.1017/Soo20818304581043.

Klinken, G. van (2009). Patronage Democracy in Provincial Indonesia. In O. Törnquist, N. Webster \& K. Stokke (eds.) Rethinking Popular Representation. New York: Palgrave Macmillan. 
Lyttleton, C., Beesey A. and Sitthikriengkrai, M. (2007). Expanding Community through ARV Provision in Thailand. AIDS Care, 19:S1, 44-53. doi:10.1080/09540120601114659.

Marshall, T.H. (1950). Citizenship and Social Class. Cambridge UK: Cambridge University Press.

Merry, S.E. (2001). Spatial Governmentality and the New Urban Social Order: Controlling Gender Violence Through Law. American Anthropologist, 103(1), 16-23. doi: 10.1525/aa.2001.103.1.16.

Merry, S.E. (2006a). Transnational Rights and Local Activism: Mapping the Middle. American Anthropologist, 108(1), 38-51. doi: 10.1525/aa.2006.108.1.38.

Merry, S.E. (2006b). Human Rights and Gender Violence. Translating International Law into Local Practice. Chicago: University of Chicago Press.

Munger, F. (2006/2007). Culture, Power, and Law: Thinking About the Anthropology of Rights in Thailand in an Era of Globalization. New York Law School Law Review 51, 817-838. http://connection.ebscohost.com/c/speeches/ 25292716/culture-power-law-thinking-about-anthropology-rights-thailand-era-globalization.

Munger, F. (2007). Constitutional Reform, Legal Consciousness, and Citizen Participation in Thailand. Cornell International Law Journal 40, 455-475. http:// scholarship.law.cornell.edu/cilj/vol4o/iss2/5.

Nguyen, V.-K. (2010). The Republic of Therapy: Triage and Sovereignty in West Africa's Time of AIDS. Durham and London: Duke University Press.

Niprapa Kreudhutha, Boripat Donmon, Kamon Upakaew, Cawthorne, P., Onanong Bunjumnong, Wilson, D., Ford, N. (2005). Experience of a Community-Based Antiretroviral Buyers' Club in Thailand. Essential Drugs Monitor 34, 10-11. doi: 10.1111/j.1365-3156.2009.02218.x.

Nowak, Manfred; Karolina M. Januszewski and Tina Hofstätter (2012): All Human Rights for All. Vienna Manual on Human Rights. Wien: Intersentia/Neuer Wissenschaftlicher Verlag.

Pongphon Sarnsamak (2013a). Thai-EU trade talks could kill cheap life-saving medicines. The Nation, September 3, 2013. http://www.nationmultimedia.com/ national/EU-trade-talks-could-kill-cheap-life-saving-medici-30214017.html.

Pongphon Sarnsamak (2013b). Protest in Chiangmai against THai-EU FTA. The Nation, September 18, http://www.nationmultimedia.com/national/Protest-in-Chiang-Mai -against-Thai-EU-FTA-30215106.html.

Pye, O. \& Schaffar, W. (2008). The 2006 Anti-Thaksin Movement in Thailand: An Analysis. Journal of Contemporary Asia, 38(1), 38-61. doi: 10.1080/0047233 0701651945 .

Rachman, N.F. (2013). Undoing Categorical Inequality. Masarakat Adat, Agrarian Conflicts, and Struggle for Inclusive Citizenship in Indonesia. Paper presented at the KITLV, Leiden, 13 June 2013. 
Robins, S. (2004). 'Long Live Zackie, Long Live': AIDS Activism, Science and Citizenship after Apartheid. Journal of Southern African Studies, 30(3), 651-672. doi: 10.1080/0305707042000254146.

Robins, S. (2006). From 'rights ' to 'ritual': AIDS activism in South Africa. American Anthropologist 108(2), 312-323. doi: 10.1525/aa.2006.108.2.312.

Robins, S. \& Lieres, B. von (2004). AIDS Activism and Globalization from Below: Occupying New Spaces of Citizenship in Post-Apartheid South Africa. IDS Bulletin 35(2), 84-9o. doi: 10.1111/j.1759-5436.2004.tboo125.x.

Robins, S., Cornwall, A. \& Lieres, B. von, (2008). Rethinking 'Citizenship' in the Postcolony.Third World Quarterly, 29(6), 1069-1086, doi:10.1080/01436590802201048.

Ross, R. Wilaiphan Sawatphanit, Draucker, C.B., Tatirat Suwansujarid (2007). The lived experiences of HIV-positive, pregnant women in Thailand. Health Care For Women International 10, 28(8), 731-744. doi: 10.1080/07399330701465218.

Schaffar, W., (2011) Widerständige ländliche Bewegungen und die „Kunst, nicht regiert zu werden. In M. Bruch, W. Schaffar, P. Scheiffele (eds.) Organisation und Kritik. (pp. 137-169). Münster: Dampfboot.

Schaffar W. (2014): Schwellenländer als neue Akteure globaler Normsetzung am Beispiel des Patentschutzes auf Medikamente. In A. Nölke, C. May \& S. Claar (eds.) Der Aufstieg der großen Schwellenländer in der Weltwirtschaft: Ein Handbuch. (pp. 339-355). Wiesbaden: Springer VS.

Schramm, B. (2002). Sozialpolitik in Thailand. Die Entwicklung eines Wohlfahrtsstaates zwischen Paternalismus und Moderne. [Mitteilungen des Instituts für Asienkunde Hamburg, Band 347]. Hamburg.

Schulte Nordholt, H. (2011). Decentralization and Democracy in Indonesia: Strengthening Citizenship or Regional Elites?. In D. Robison (ed.), Handbook of Southeast Asian Politics. (pp. 229-241). Oxford: Routledge.

Schulte Nordholt, H. \& Klinken G. van (eds.). (2007). Renegotiating Boundaries: Local Politics in post-Suharto Indonesia. Leiden: KITLV Press.

Smith, R.M. (2002). Modern Citizenship. In: Engin F. Isin \& Bryan S. Turner (eds.). Handbook of Citizenship Studies. (pp. 105-116), London: Sage.

Somchai Phatharathananunth (2006). Civil Society and Democratization. Social Movements in Northeast Thailand. Copenhagen: NIAS Press.

Spivak, G.C. (1985). The Rani of Simur. In F. Barker et al., (eds.). Europe and its Others. Vol. 1., (pp. 247-272). Colchester: University of Sussex.

Sripen Tantivess \& Gill, W. (2008). The role of state and non-state actors in the policy process to the scale-up of antiretroviral therapy in Thailand. Health Policy and Planning 23(5), 328-338. doi: 10.1093/heapol/czno23.

The Asia Foundation (2013). Profile of the Protestors. A Survey of Pro and Anti-Government Demonstrators in Bangkok on November 30, 2013. Bangkok. http://asiafoundation.org/resources/pdfs/FinalSurveyReportDecember2o.pdf. 
Thongchai Winichakul (2008a). Nationalism and the Radical Intelligentsia in Thailand. Third World Quarterly 29(3), 575-591. doi: 10.1080/01436590801931520.

Thongchai Winichakul (2008b). Toppling democracy. Journal of Contemporary Asia, 38(1), 11-37. doi: 10.1080/00472330701651937.

Tilly, C. (1995). Citizenship, Identity and Social History. International Review of Social History, 4o(SupplementS3), 1-17. doi: 10.1017/Soo20859000113586.

UN (1979). Convention on the Elimination of All Forms of Discrimination against Women (CEDAW) [adopted on 18 December 1979]. http://www.un.org/womenwatch/ daw/cedaw/

UN (2009). Legal empowerment of the poor and eradication of poverty. Report of the Secretary-General, A/64/133. http://www.un.org/esa/socdev/documents/reports/ Legal\%2oempowerment\%2oof\%2othe\%2opoor.pdf

Walker, A, (2012). Thailand's Political Peasants. Power in the Modern Rural Economy. Madison: University of Wisconsin Press.

Weeraboon Wisartsakul (2004). Civil Society Movement to Revoke the Thai Patent on ddI, Bangkok: Medecins sans frontiers - Belgium (MSF-B).

WTO (2001). Declaration on the TRIPS Agreement and Public Health. [adopted on 14 November 2001], WTO Ministerial Conference, Fourth Session, Doha, 9-14 November 2001, WT/MIN(01)DEC/. 